\title{
Nova Pulse Power Design and Operationa] Experience
}

K. Lhithan, D. Larson, B. Merritt, D. Christie

This paper was prepared for submittal to

SPIE Optoelectronics \& Laser

Applications

January 1987

This is a preprint of a paper intended for publication in a journal or proceedings. Since changes may be made before publication, this prepriat is made available with the - understanding that it will not be cited or reproduced without the permissinn of the author.

\section{WSCLAIMER}

This report was prepared as an accounl of work sponsored by an agency of the United Stales Government. Neither the United States Government nor any agency the reof, nor any of their employees, inakes any warranty, express or implied, or assumes any legal liability or responsibility for the accuracy, completeness, or usefulness of any information, apparatus, product, or process disclosed, or represenls that its use would not infringe privately owned rights. Relerence herein to any specilic commercial produc1, process, or service by trade name, trademark, manufacturer, or otherwise does not necessarily constitute or imply its endorscment, recommendatinn, or lavorin, by the United States Govemment ar any agency thercof. The views and opinions of authors expressed herein do not nesessarily state or reflect those of the United States Governmest of any agency thereof. 


\section{abtract}

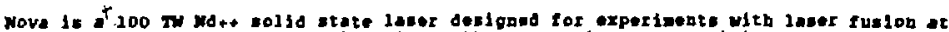

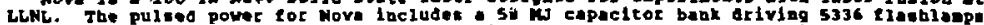
Heh elilisecond pulzes and subnengsecond blgh voltages lor electro upties. This paper sunerixes the puited pover desigos and the operationel experience to date.

\section{5y+2015x}

There are tev lasere the size of Mova and fou capacitor banks the size of the wove bank. Fron the potat of vies of operational experteace and parte rellabilicy alone. the Wova bank 1s a lateroeting entity.

The Noya bank 18 complised of 1827 seperate energy storege circulit wate up of 10400

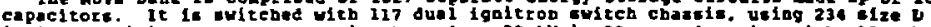

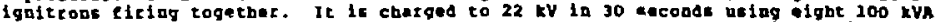

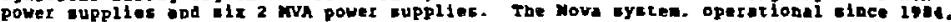
has 700 systen abote and thousands of front end abote.

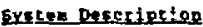

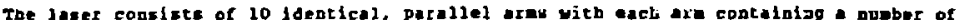
disk anplifiers, rod amplifiers and raraday cocators. Figuze 1 ehews che staging of these eloweats ad the energy required for ach of chen.

Table I, Gank Lyout

\begin{tabular}{|c|c|c|c|c|c|c|c|c|c|}
\hline & $\begin{array}{c}\text { Number } \\
\text { per } \\
\text { arm }\end{array}$ & $\begin{array}{c}\text { Toual } \\
\text { number of } \\
\text { componens }\end{array}$ & $\begin{array}{l}\text { Number } \\
\text { of } \\
\text { encuits }\end{array}$ & $\begin{array}{c}\text { Total } \\
\text { numbex } \\
\text { of } \\
\text { cincuits }\end{array}$ & $\underset{\substack{\text { Envery } \\
\text { (kd) }}}{\substack{\text { compont } \\
\text { (k) }}}$ & $\begin{array}{c}\text { Entery } \\
\text { perr. } \\
\text { eincuit } \\
\text { (IN) }\end{array}$ & 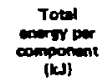 & $\begin{array}{l}\text { Number of } \\
\text { thenlempo } \\
\text { perinesit }\end{array}$ & $\begin{array}{c}\text { Tobl } \\
\text { number } \\
\text { of } \\
\text { tilenlamp }\end{array}$ \\
\hline \multicolumn{10}{|c|}{ Component } \\
\hline $\begin{array}{l}\text { Aods } \\
\text { Splitter }\end{array}$ & $\begin{array}{l}1 \\
6\end{array}$ & 16 & 1 & 16 & EO & 50.0 & $00-12.5$ & 6 & $85-10$ \\
\hline 9.4 dize & 2 & 20 & 8 & 160 & 174 & $18.0^{*}$ & $2000-3$ & 2 & $320-44^{\prime \prime}$ \\
\hline $\begin{array}{l}\text { 9.4 F.R. } \\
\text { Splitter }\end{array}$ & 1 & 11 & 1 & 11 & 21 & 21.0 & $231-3$ & & \\
\hline 15 dixe & 1 & 10 & 12 & 120 & 261 & 18.0 & $2160-3$ & 2 & $240-4 *$ \\
\hline 15 F.R. & 1 & 10 & 4 & 40 & 160 & 37.5 & $1500-125$ & & \\
\hline 20.8 disc & 3 & 30 & 8 & 240 & 200 & $21.0^{\circ}$ & $5040-3$ & 2 & $480-44^{\prime \prime}$ \\
\hline 20.8 F.R. & 1 & 10 & 5 & 50 & 200 & 40.0 & $2000-5$ & & \\
\hline 31.5 disc & 5 & $\begin{array}{l}32 \\
18\end{array}$ & $\begin{array}{l}10 \\
10\end{array}$ & $\begin{array}{l}320 \\
180\end{array}$ & $\begin{array}{l}375 \\
375\end{array}$ & $\begin{array}{l}33.0^{\circ} \\
37.5^{\circ}\end{array}$ & $\begin{array}{c}10560-3 \\
6750-12.5\end{array}$ & $\frac{2}{2}$ & $\begin{array}{l}640-44 " \\
360-4 \%\end{array}$ \\
\hline 31.5 F.A. & 1 & 10 & $\mathbf{5}$ & 50 & 200 & 40.0 & 2000.5 & & \\
\hline \multirow[t]{2}{*}{46 dise } & 4 & 40 & 16 & 640 & 600 & 37.5 & $24000-12,5$ & 5 & $3200-49$ \\
\hline & & & & $\begin{array}{l}1827 \text { lotal } \\
151 \text { F.R. } \\
2676 \text { lamp }\end{array}$ & & & $\begin{array}{c}33050-125 \\
4000-5 \\
20371-3\end{array}$ & & $\begin{array}{l}3296-19 " \\
2040-44 "\end{array}$ \\
\hline
\end{tabular}

Figure 1, Bank Layout 


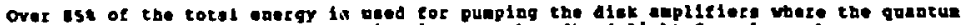

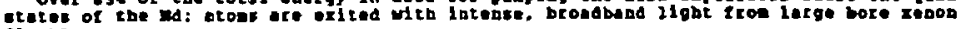
Ilachlonpe.

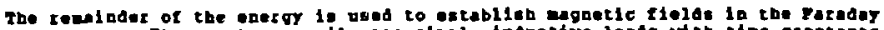

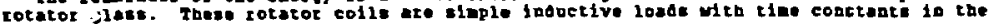
cliliecona regine.

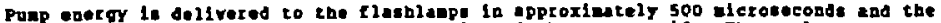

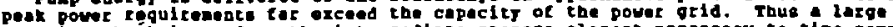

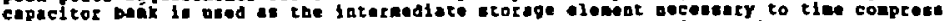

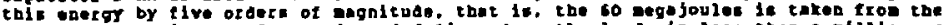
grld over period of 30 seconds apd deilvered to the loads in lots than a villescond.

\section{Derigp extrite}

The Move Laser porer conditionigg ua destgnod to alninire cort lor a giveo

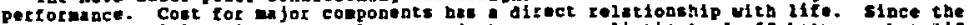

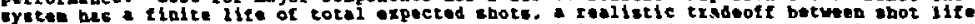

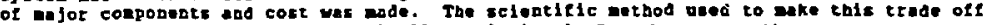

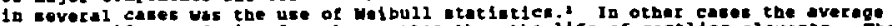
expered lice vat desigaed to be greater then the life of cortier elesentr. The

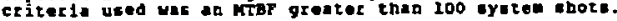

\section{subsyctersengonent Derectetion}

Figure 2 shous the pout conditioning citcult. The enjot conponente are described it

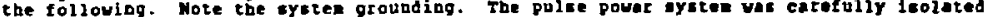

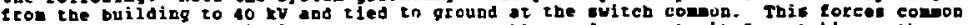

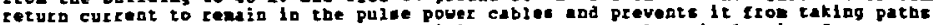
through the bullajag teel. Thls is critical co preveat electrical nolse frop interteriog uith mensitive alagnonick and conputer control. Hith 10 wh of pulend curtent flowing. It is a important cansiderarion.

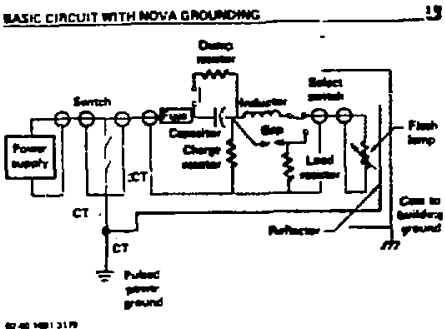

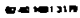

Figure 2. Basie Hova Circuit

\section{Pover supplieg}

The pouer supply cize vas chosen to conpleaent the capacitor life. Each capacitor has - Iinite life at tuli voltage. By cbarging rapidiy, tbe tiee at volcage í reduced. However, the cost of the power cupplies increaces with the kva ratigg, so there ib a crobs-over where the cost raved in capaclzor lize is nore than spent in pouer $64 p p l y$ capacicy. This analyeic was done to size the total power supply completent. The aize of individual cupplies was chosen for convenience of craging and vich do actept to naxibize 
the sire tor ecoponies of ecele. A roltege doubler ouppiy-trpe was chonen to achleve

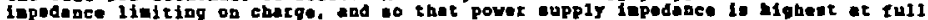
volige. coducing raule probienc. He used roltage doublete on prior gretens and were

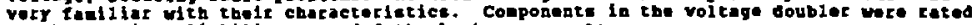
co cant theif rellobility excedes the bank conponente.

To date. tbe power eupplien have parfored 700 charge cycles. Teliures arsociated

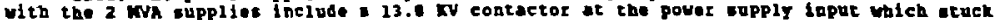
closed and several solid tise doloy relays uged for power supply control. The 100 and eupplies operete with phese controlied ied $v$ inpues. Fallures with these supplies Include tour.patrs of phace control sCR' and several fallures of control conponente.

\section{5uttaine}

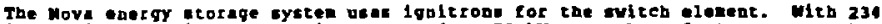

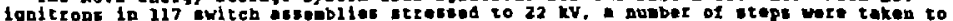
Iasur reliable operation of these tubes. The nost troublesos aspet of lgnitrone in a large population is randon prefire. Wh wora. prefire caucer cavaral sycten problese.

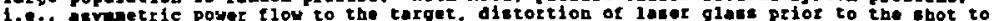
aave tro. To avold prefira. neu tubec are bougte to etriet epecification. In adation. the catbode of act tube le vater cooled to $26^{\circ} \mathrm{C}$ and the anode heaced to $50^{\circ} \mathrm{c}$ co igsure meccury is pot copdensing on the anode. The tubes ere perlodically blgb-ported

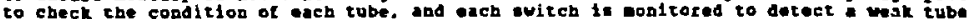
so that it can be replaced before beconing a cycten problen. Current detectora are placed on trlgger leads and on the ain current leg of each tobe. These are mopltored by

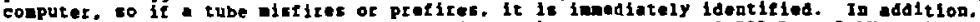
co prevent disfire, aul criggers are used at trigger currents of $500 \mathrm{n}$ at 2 rv to fasure turb on. Jitres ls not an isue with tbese pulse iengths. Jitter of the oraer of one aferonecond is typicaliy recorded for che 1quitrons.

The fova gitch argeblies have proven vary reliable. The noninal operatiog

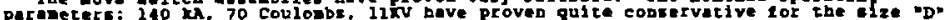

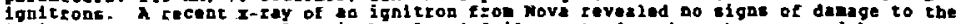
ignitar or enode. The only puiteb related faliures to date have been caused by poor connectione of the anode lug. Prefire frequency has besn recy low.

\section{Capeclipere}

One of the ajor cost areas for the wova wiser was capacitore. In order to decreace capacitor cost. We copducted a progran to increace capacitor energy density. Three capacieor compinies vere relected to develop new capacitors with 12.5 bJ energy etored at

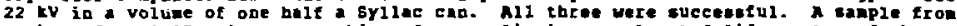
ach vendor of 35 unite vere subjected to realietie. acceleraced lite tests and the Helbul curve dram. The systen could then be decigand with a know capacitor life and capacitor MTBF for pulsed discharge." Figure 3 shour the capacicor price as a function of energy deatity in 1980 dollars. Figure thous the Weibull curve for tyo sets of capacitore tor Mova.

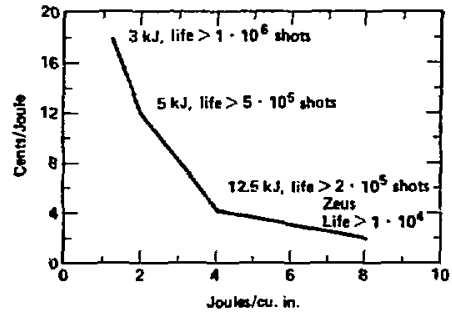

Plgure 3. Capscitor Cost ve Energy Density

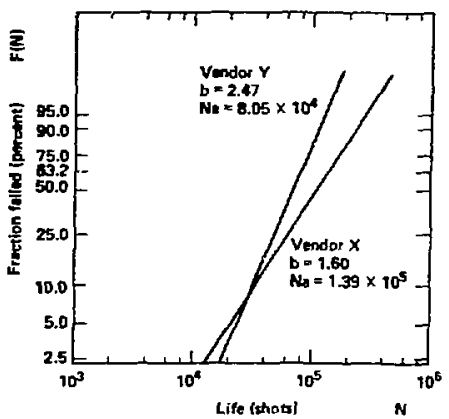

Figure 4. Sabple Capacitor Velbull-Curves 


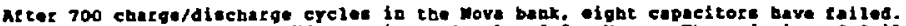

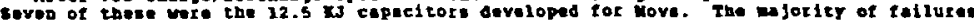
have bea interand bhort ciculte fron buching to the capacitor case.

\section{Enerov stereqe Hodules}

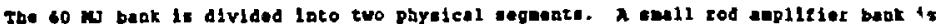

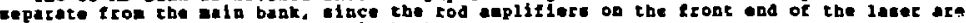
ured web Dofe often than the mola bank.

The banks ere eggented lato individuel modules for each glechlan ar rotator clrccit. A nodule conslete of two to eleven cepacitors and pulee forming netuork (PFN) boaro. The PFM board conatsts of a puse absplng inductor, rharge resistor. tuse, douploy resistore and oumy load.

The modules are sized a noalos $20 \mathrm{~kJ}, 37.5 \mathrm{~kJ}$, ad $50 \mathrm{~kJ}$ units 2 or tlashlap

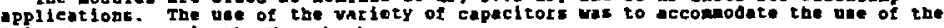
Shive bank parte in the wova bakk.

The nodules are actenbled as units on trayc and can be renoved frov the nounciag racks

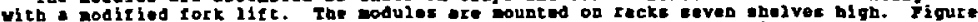

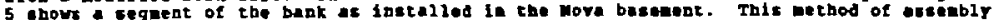
was chosen to be abie to change godul ulthin an hour. Tbe copcept vas to $110 y$

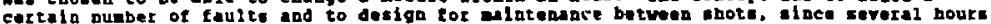
take place betuen ebots.

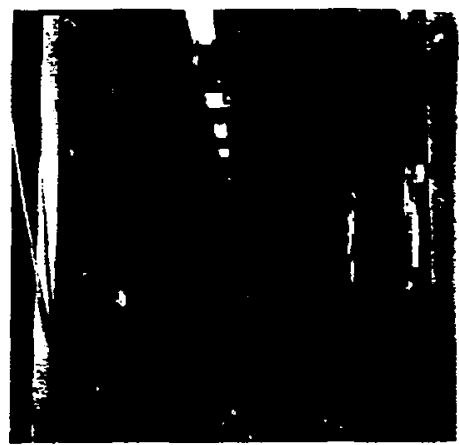

Figur: 5. Nlele of Nova Bank

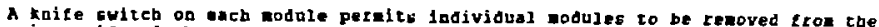
charging grid and thorted. Manui operation of this culech vith a long graundipg rod

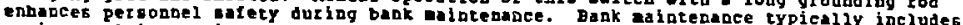

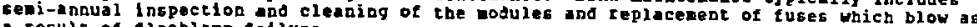
a resulc of tiashlap tallure

\section{High Power Besiscors}

Since shiva, conciderable efforc was made to inprove high powet resistors. In particulor. extensive testing yas performed on resictors for vo as dupny loads aud dumps. The dumey loid is an alternate loso for the energy storage dodules. The dumps are used in the crowbar gyeten to saxe the capacitors in the modules. Sasples of these resictorg ace shown in Figure 6 . 


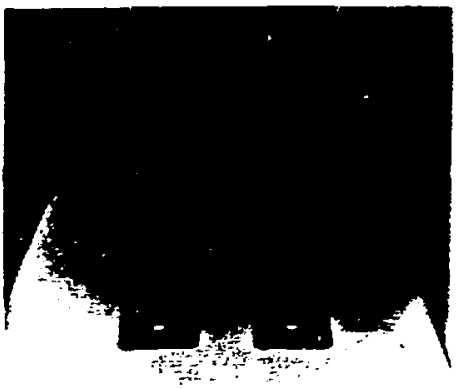

Fiqure 6. Hove High Power Berlstors

The auny lodd resistors vere used during bab contruction to rbesa out the bank cabling and controlx without requiring connection to a laser enplifier. They are nou used periodically for troubleshooting the gysten. Hone of these resietors has tailed,

The dupp resistors are used to discharge portions of the babk hi=b were not required

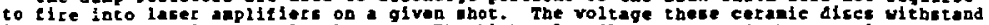

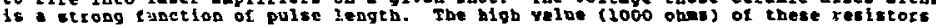
result in tine contrant of about 150 villimeconds. Of the 1000 dunp recketors in tbe bagk. there have been ixty failures due to voltage strese. Thic problen is being oolved by lncreasing the lengtb of tbe asseably fron four to tive inches.

The requireneute for the duny loads are an iapedace or approximately 5 ohms. an energy capability of $50 \mathrm{~kJ}$, and goliage rating of $22 \mathrm{kv}$. We uce ceranic diec cesiftors.

Tbe requirenepts tor the durp renlstor are a imponce of 1000 ohat. ad energy capabilicy of oD rJ sigle pulse. and a volinge racing or $23 \mathrm{kV}$.

\section{Plashlap toeds}

The tlachlanp long are uced to exclte the Ndth ions in the lacer glass, The diensiont of the tlashlapps vere chosen for aplifier requireaenc. The ians are filled with repon gas at a prescure of 300 torr. About balt the lape are $1.1 \mathrm{n}$ in leagth. $1.5 \mathrm{co}$ boze and have ceriun doped quartz valis to dapen the uy to extend anplifier life vithout causing loss in pung officiency. The ronainder of the laps are

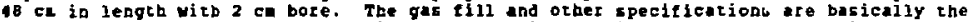
rane. The laps are nonlinear recistive loads with two inpedance tates. h high voltage pulbe is required to beak down the lap. At ter the lamp is ionizeo. che voltage dad cutreat are related by

$$
V=K I^{B}
$$

Where $K$ relates to the lanp geonetry and gas $f i l l$ and $B$ is about .5 at curzent maxinum. The peak curgent is bout $6 \mathrm{kh}$ and the peak voltags drop at current aax is $10 \mathrm{kV}$.

Lanp reliabiltry is a eritical issue vitb glase lagers. The rotal number of lanps for Nova is 5336 . To insure adequate reliablitiy. the lamps ire purchased to a compehensive epecificarioa requirlag electrical and mechanical inspections the vendor agd at LLWL. Each lawp undergoes aicroscopic inspection. $60 \mathrm{kV}$ bipot, and accelerated high pouer testing prior to use. In ardicion. before edey loser bbot, a lau pouer (l2 pover) discharqe is given to each lanp and waveform aze ganned by the conputec to look for weak or aiging waverorms. These lanps are then replaced before they arc tired are full power. 


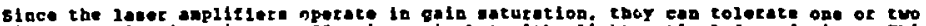

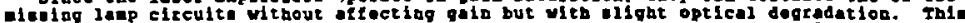

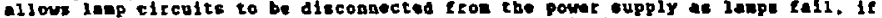
necesery. The lampe ore roplaced after several tall la tho ane are of the lober. To dete. Iose than two percent of the lapps on Hov have labled. Host of tho fallures are

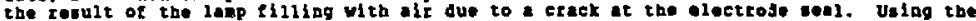
techaique of replectog falled lanps at convenient time af ter ceveral have failed allove the eyctar to natheis an acceptable MTBF.

$\mathbf{t}$

\section{Rerpary poticors}

About tea percent of tbe bank energy Is used to arive pulced colla for Farader rotators. These devices act as optlcal dioder co provent cefloctad light from being anplified il the revere direction in the orsten. The rotator eircules ach bave

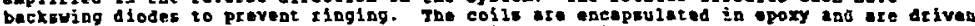
yitb up to $200 \mathrm{~kJ}$ of enezgy and $15 \mathrm{kA}$ to achleve the flelds necereary for the rotetor giess. The only fallure ascociated with tbe faraday rotators bave been due to breakdoun of the diode stack arsembiles.

\section{Conclusions}

The desigu cossideratinns ufed tor the Nova pulee Power have been succestul. Tbe approseb of using Helbuli tatietice te deslga lallure rates to acbieve cost poals is a vible techoique for desigaing large systes. The actual parforance of tbe conponents

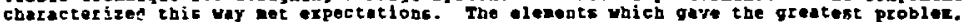
high pouer zesietorc. are being nodified to have aor concesvative design.

Work petfored udder auspices of DOE by LLHl, under contract Ho. W-7405-Eng-48.

\section{Reterences}

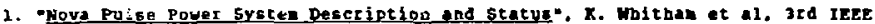
international Pulce Pouer Conference. June 1901.

2. B. Wercitr and K. Whithaw, "Pertorunge and Cobt Analycic of Large Capacitor Banke Using Heibull stotistics ind risP" 